\title{
Effect of Grape Seed Procyanidins Extract on Lipolysis in Rats
}

\section{Fangxu $X^{1}$, Yefei $L^{1}$, Xinzhe $Z^{2}$ and Shengzhong $D^{1 *}$}

${ }^{1}$ Experimental Teaching Center, Shenyang Normal University, Shenyang, Liaoning, People's Republic of China

${ }^{2}$ College of Life Science, Shenyang Normal University, Shenyang, Liaoning, People's Republic of China

\begin{abstract}
The objective of this study was to investigate the effects of grape seed procyanidins extract (GSPE) on lipolysis in rats. Body weight, serum lip level, glucose tolerance, insulin tolerance and gene expression level of FAS, ACC1, Cpt1a and HSL in liver of standard diet (SD) or high fat diet (HFD) treated rats by gavage were measured. The results showed that $150 \mathrm{mg} \mathrm{kg}-1 \mathrm{~d}-1$ of GSPE is effective in decreasing body weight, serum lip level and blood glucose value of SD and HFD treated rats compared to control. Meanwhile, GSPE can improve the trend of high blood glucose and insulin resistance in obese rats and show the dose-independent manner. Furthermore, application of $150 \mathrm{mg} \mathrm{kg}-1 \mathrm{~d}-1$ GSPE was found to be most effective in suppressing FAS and ACC1 genes expression levels and increasing Cpt1a and HSL genes expression levels in liver of SD $(P<0.05)$ and HFD $(P<0.01)$ treated rats compared with the control treatment. Based on these results, we concluded that GSPE can inhibit the lipid deposition of HFD treated rats, furthermore, it can also influence the gene expression levels of related with lipid metabolism and the glucose-tolerance and insulin-tolerance to co-regulate the lipid metabolism in obese rats.
\end{abstract}

Keywords: Grape seed procyanidins extract; Lipolysis; Gene expression; Real-time PCR; Rats

\section{Introduction}

Obesity has become a very serious social problem that severely endangers the public health [1,2]. It means an over-deposition of fat results from disequilibrium of lipid metabolism and to much intake of calorie, which closely associated with the occurrence of diabetes, hypertension, cardiovascular and cerebrovascular diseases and insulin resistance [3-5]. Clinical studies have shown that obesity is an independent risk factor of diabetes and cardiovascular and cerebrovascular diseases which affect blood pressure, blood glucose and serum lipid level [6-8]. Procyanidins (PC) as a kind of natural powerful antioxidant has been proven to have the function of antioxidation and radical scavenging action which derived from fruit, vegetable, nut, seeds, flowers and pericarp [9]. It is reported that the antioxidative and absorbing ability of PC from seeds is better than the others [10]. Studies shows that the content of PC is high in species of grape seeds, and PC is the main polyphenols in grape seed extract [11,12]. Lluis and Yamakoshi have demonstrated that PC and grape seed procyanidins extract (GSPE) have no toxicity to rats or negative effects on their growth by micronucleus and bacterial reverse mutation tests, which can be widely used $[13,14]$. As the source of PC, GSPE has obtained much attention from many authors, and deeply developed during recent years [15-17]. So far, there have been few reports on the effects of GSPE on prevention and treatment of obesity. It has been reported that PC can decrease body weight [18], triacylglycerol (TAG), aliphatic acid and the concentration of low density lipoprotein cholesterin (LDL-C) of rats [10]. Pinent has reported that PC is effective in decreasing blood glucose level and improving insulin resistance of rats by regulating the signal path of insulin. The aim of our study is to evaluate the efficiency of 50, 100 and $150 \mathrm{mg} \mathrm{kg}^{-1} \mathrm{~d}^{-1}$ of GSPE in decreasing body weight, serum lip level and blood glucose value, improving the trend of high blood glucose and insulin resistance, suppressing FAS and ACC1 genes expression levels and increasing Cptla and HSL genes expression levels in liver of standard diet (SD) or high fat diet (HFD) treated rats by gavage, and to illuminate the effect of GSPE on fat deposition and provide a basis for action mechanism of anti-obesity of GSPE.

\section{Materials and Methods}

\section{GSPE preparation}

GSPE is a polymer with catechinic acid, epicatechin and gallate covalent bonds by $\mathrm{C}_{4}-\mathrm{C}_{6}$ or $\mathrm{C}_{4}-\mathrm{C}_{8}$. GSPE powder was obtained from Tianjin Jianfeng Natural Product Rand D Co., Ltd, China and the purity was above $95 \%$ which stored in a sealed and light-sensitive package until being dissolved in ultrapure water prior to use. The GSPE powder utilized in our study was obtained from the same source with the same batch number.

\section{Animals and experimental design}

Eighty male Kunming rats ( $12 \pm 2 \mathrm{~g}$ ) were provided by Laboratory Animal Center, Shenyang Medical College and maintained in animal facility at controlled temperature $\left(23 \pm 2{ }^{\circ} \mathrm{C}\right)$ with a 12 -h light/dark cycle. Preliminary experiment indicated that $50 \mathrm{mg} \mathrm{kg}^{-1} \mathrm{~d}^{-1} \mathrm{GSPE}$ was the lowest concentration that gave an obvious lipolysis. So these rats were divided into 4 groups of twenty rats each, which were treated by gavage as follow: (1) untreated; (2) with $50 \mathrm{mg} \mathrm{kg}^{-1} \mathrm{~d}^{-1}$ of GSPE; (3) with $100 \mathrm{mg} \mathrm{kg}^{-1} \mathrm{~d}^{-1}$ of GSPE; (4) with $150 \mathrm{mg} \mathrm{kg}^{-1} \mathrm{~d}^{-1}$ of GSPE. Then half of every group was fed with SD and the others were fed with HFD for 16 d. The SD consisted of 5\% fat, $70 \%$ carbohydrate, and $25 \%$ proteins, and the HFD consisted of $39 \%$ fat, $45 \%$ carbohydrate, and $16 \%$ protein [19]. Body weight was measured every $4 \mathrm{~d}$. The rats were fasting for 12 $\mathrm{h}$ before experiment, and the rats were killed by cervical dislocation. Their blood was collected, and plasma processed for serum lip level assessment and the adipose tissue from liver region was carefully dissected for expressions of lipid-associated genes assessment.

*Corresponding author: Shengzhong D, Experimental Teaching Center Shenyang Normal University Shenyang, Liaoning, People's Republic of China, Tel: +862486574436; E-mail: 36914789@qq.com

Received October 20, 2017; Accepted November 06, 2017; Published November 10, 2017

Citation: Fangxu X, Yefei L, Xinzhe Z, Shengzhong D (2017) Effect of Grape Seed Procyanidins Extract on Lipolysis in Rats. J Bioprocess Biotech 7: 312 doi:10.4172/2155-9821.1000312

Copyright: @ 2017 Fangxu X, et al. This is an open-access article distributed under the terms of the Creative Commons Attribution License, which permits unrestricted use, distribution, and reproduction in any medium, provided the original author and source are credited. 


\section{Measurement of serum lip level}

Total cholesterol (TC) was determined by COD-PAP method. $2 \mu \mathrm{L}$ of serum was added in a elisa plate of 96 holes (Sino-American Biotechnology Co., Ltd., China) with a $2 \mu \mathrm{L}$ quantitative pipettor, and $2 \mu \mathrm{L}$ of standard liquid and $200 \mu \mathrm{L}$ enzyme liquid were added in the standard orifice. TC content $\left(\mathrm{mmol} \mathrm{L}^{-1}\right)$ was determined at $650 \mathrm{~nm}$ with an ELISA biochemical analyzer (ZS-2, Beijing Xinfeng Electromechanical Technology Co., Ltd., China), after thoroughly mixing at $37^{\circ} \mathrm{C}$ for $10 \mathrm{~min}$. TAG was determined with glycerol phosphate oxidase method. $10 \mu \mathrm{L}$ of distilled water and $1000 \mu \mathrm{L}$ of enzyme liquid were added in the blank tube, and $10 \mu \mathrm{L}$ of standard liquid and $1000 \mu \mathrm{L}$ of enzyme liquid were added in the standard tube. In addition, $10 \mu \mathrm{L}$ of serum and $1000 \mu \mathrm{L}$ of enzyme liquid were added in the detected tube. After thoroughly mixing at $37^{\circ} \mathrm{C}$ for $5 \mathrm{~min}$, TAG content was determined at $500 \mathrm{~nm}$ with an ELISA biochemical analyzer (ZS-2, Beijing Xinfeng Electromechanical Technology Co Ltd China). TAG content $\left(\mathrm{mmol} \mathrm{L}^{-1}\right)=($ A of detected tube/A of standard tube $) \times$ 2.26. High density lipoprotein cholesterol (HDL-C) and LDL-C were determined with phosphotungstic acid-magnesium precipitation method [20] and enzyme directory method [21]. HDL-C and LDL-C were conducted according to the operation instruction of HDL-C and LDL-C Reagent Kit (Zhongsheng Beikong Bio-Technology and Science Inc, China).

\section{Measurement of glucose tolerance}

Fasted rats were injected intraperitoneally with glucose $(2 \mathrm{~g}(\mathrm{~kg}$ body weight $)^{-1}$ ). Blood samples were taken from the tip of the tail to determine blood glucose before $(0 \mathrm{~min})$ and after the glucose injection $(30,60,90$ and $120 \mathrm{~min})$. The glucose response to glucose tolerance was calculated as the area under the glucose curve for each rat (SPSS Inc Chicago USA) [22].

\section{Measurement of insulin tolerance}

Fasted rats were injected intraperitoneally with insulin $(0.75 \mathrm{IU}(\mathrm{kg}$ body weight $)^{-1}$ ). Blood samples were taken from the tip of the tail to determine blood glucose before $(0 \mathrm{~min})$ and after the insulin injection $(30,60,90$ and $120 \mathrm{~min})$. The glucose response to insulin tolerance was calculated as the area under the glucose curve for each rat (SPSS Inc Chicago USA) [22].

\section{RNA extraction and CDNA preparation}

Total RNA from epididymal adipose tissue of rats was extracted according to the instructions of RNAiso ${ }^{\mathrm{TM}}$ Plus (TaKaRa Code: D9108A). Reverse transcription (RT) was conducted as follows according to the instructions of PrimeScript RT Reagent Kit Perfect Real Time (TaKaRa Code: DRR037A). RNA template (500 ng), $5 \times$ PrimeScript buffer $(2 \mu \mathrm{L})$, $50 \mu \mathrm{M}$ Oligo dT Primer $(0.5 \mu \mathrm{L})$, PrimeScript RT Enzyme Mix I $(0.5 \mu \mathrm{L})$ and DEPC treated water $(7 \mu \mathrm{L})$ were mixed in $0.1-\mathrm{mL}$ eppendorf tubes at $37^{\circ} \mathrm{C}$ for $15 \mathrm{~min}$. The tubes were immediately put into ice for $5 \mathrm{~min}$. The products of RT were stored at $-20^{\circ} \mathrm{C}$ for future use.

\section{Real-Time PCR analysis}

The mRNA was quantified by using real-time PCR (ABI Prism 7700 , USA). The primers were designed on the basis of common sequences with the Primer Express software 5.0 (Applied Biosystems) and synthesized by Beijing Dingguo Biological Technology Co Ltd China (Table 1). The premix mixture for real-time PCR Master Mix was produced by Beijing Dingguo Biological Technology Co Ltd China. Real-time PCR was carried out with the real-time PCR Master Mix according to the manufacturer's instructions. Each reaction contained template cDNA $(1.0 \mu \mathrm{L}), 10 \mu \mathrm{M}$ sense primer $(0.8 \mu \mathrm{L}), 10 \mu \mathrm{M}$ antisense primer $(0.8 \mu \mathrm{L})$, SYBR Premix Ex Taq ${ }^{\mathrm{TM}}$ (TaKaRa Code: DRR081S) $(10.0 \mu \mathrm{L})$ and $\mathrm{RNase}$-free $\mathrm{ddH}_{2} \mathrm{O}(7.4 \mu \mathrm{L})$. The total volume of the reaction system was $20 \mu \mathrm{L}$. The thermal cycling conditions were $95^{\circ} \mathrm{C}$ for $10 \mathrm{~s}$ followed by 40 cycles of $95^{\circ} \mathrm{C}$ for $5 \mathrm{~s}$ and $60^{\circ} \mathrm{C}$ for $35 \mathrm{~s}$. Real-time quantitative RT-PCR was performed in three replicates for each sample.

\section{Statistical analysis}

Analyses of data were carried out by one-way ANOVA in SPSS 16.0 for Windows (SPSS Inc., Chicago, IL, USA). Statistic differences were considered to be significant at $\mathrm{P}<0.05$ by Duncan's multiple range test. All results were expressed as the mean $\pm \mathrm{SE}$.

\section{Results}

\section{Effect of GSPE on body weight}

In the present study, the results showed that body weight of SD and HFD treated rats gradually increased. There was decrease in body weight of various doses of GSPE-treated rats in comparison with control group, but no statistically significant difference $(\mathrm{P}>0.05)$ was found between the body weight of untreated and every doses of GSPE-treated rats during the first four days (Figure 1). Results showed that body weight of $150 \mathrm{mg} \mathrm{kg}^{-1} \mathrm{~d}^{-1}$ of GSPE-treated rats were significant $(\mathrm{P}<0.01)$ inhibited by approximately $7-14 \%$ (Figure 1A) and $9-17 \%$ (Figure 1B) compared to the controls from days 8 to 16 . Moreover, body weight of rats treated with $100 \mathrm{mg} \mathrm{kg}^{-1} \mathrm{~d}^{-1}$ of GSPE were significant $(\mathrm{P}<0.01)$ inhibited by $7-10 \%$ (Figure 1A) and 12-13\% (Figure 1B) from days 12 to 16 . The increase of body weight of SD and HFD treated rats were controlled by $50 \mathrm{mg} \mathrm{kg}^{-1} \mathrm{~d}^{-1}$ of GSPE, but no statistically significant difference $(\mathrm{P}>0.05)$ was observed in comparison with control group.

\section{Effect of GSPE on serum lip level}

As shown in Table 2, effect of GSPE on serum lip level of SD and HFD treated rats showed a similar trend. For SD and HFD treated rats, $50 \mathrm{mg} \mathrm{kg}^{-1} \mathrm{~d}^{-1}$ of GSPE produced no statistically significant effect on serum lip level in comparison with the control. However, in comparison to the control group, $100 \mathrm{mg} \mathrm{kg}^{-1} \mathrm{~d}^{-1}$ of GSPE noticeably $(\mathrm{P}<0.05)$ reduced TC, TAG and LDL-C and increased HDL-C of SD and HFD treated rats (Table 2). In addition, the effect of $150 \mathrm{mg} \mathrm{kg}^{-1} \mathrm{~d}^{-1}$ of GSPE on TC, TAG and HDL-C of SD and HFD treated rats were significantly $(\mathrm{P}<0.01)$ compared to the control, although no noticeable effect was detected on LDL-C compared to $100 \mathrm{mg} \mathrm{kg}^{-1} \mathrm{~d}^{-1}$ of GSPE-treated rats in the current study (Table 2). The results showed that there is significant positive correlation between TC and TAG $(\mathrm{R}=0.894, \mathrm{P}=0.05)$, and LDL-C was significantly negatively correlated with HDL-C in our study $(\mathrm{R}=-0.857, \mathrm{P}=0.05)$ (data not shown).

\begin{tabular}{|l|l|l|l|}
\hline Name & Accession Number & Gene ID & Sequence (5'-3') \\
\hline$\beta$-actin & NM_007393.2 & 11461 & F: AATCGTGCGTGACATCAA \\
\hline FAS & BC046513 & 14104 & F: $:$ GGGTCTATGCCACGATTC \\
\hline ACC1 & NM_133360.2 & 107476 & F: GGCAGCAGTTACACCACATAC \\
\hline Cpt1a & NM_013495.2 & 12894 & F: : CTCCGCCTGAGCCATGAAG \\
\hline & & & R: CACCAGTGATGATGCCATTCT \\
\hline HSL & NM_010719 & 16890 & F: GACTCACCGCTGACTTCC \\
\hline & & & R: CTGTCTCGTTGCGTTTGTA \\
\hline
\end{tabular}

Table 1: Sequences of primers and probes for quantitative analysis of genes expression with real-time PCR. 
Citation: Fangxu X, Yefei L, Xinzhe Z, Shengzhong D (2017) Effect of Grape Seed Procyanidins Extract on Lipolysis in Rats. J Bioprocess Biotech 7: 312. doi:10.4172/2155-9821.1000312

Page 3 of 6

\section{Effect of GSPE on glucose tolerance}

The effect of GSPE on glucose tolerance of SD and HFD treated rats were shown in Figure 2. As shown in Figure 2, blood glucose values of each group gradually increased and reach the peak at $60 \mathrm{~min}$ after the injection of glucose. As for SD treated rats, blood glucose value of GSPE-treated rats were all lower than the control group, but only 150 $\mathrm{mg} \mathrm{kg}^{-1} \mathrm{~d}^{-1}$ of GSPE treatment showed a statistically significant difference $(\mathrm{P}<0.05)$ compared with the control (Figure 2A). $150 \mathrm{mg} \mathrm{kg}^{-1} \mathrm{~d}^{-1}$ of GSPE treatment decreased blood glucose value by $10.9 \%$ when compared with the untreated samples at 60 min (Figure 2A). The results suggested that there was no observable effect on the change of blood glucose value for low concentration of GSPE. However, as for HFD treated rats, 50, 100 and $150 \mathrm{mg} \mathrm{kg}^{-1} \mathrm{~d}^{-1}$ of GSPE decreased blood glucose value by $2.9 \%$, $8.9 \%$ and $14.9 \%$ compared with the control at $60 \mathrm{~min}$, respectively (Figure 2B). Moreover, $100 \mathrm{mg} \mathrm{kg}^{-1} \mathrm{~d}^{-1}$ of GSPE treatment significantly $(\mathrm{P}<0.05)$ decreased the blood glucose value comparing to the control groups. Figure $2 \mathrm{~B}$ also shows that $150 \mathrm{mg} \mathrm{kg}^{-1} \mathrm{~d}^{-1}$ of GSPE was the most effective in decreasing blood glucose value of HFD treated rats, and this was significant $(\mathrm{P}<0.01)$ when compared with control samples. This indicated that $150 \mathrm{mg} \mathrm{kg}^{-1} \mathrm{~d}^{-1}$ of GSPE was potential for improving the ability of decrease blood glucose value of HFD treated rats.

\section{Effect of GSPE on insulin tolerance}

Insulin tolerance in our study showed an opposite trend comparing with glucose tolerance, and showed was a negative relationship with glucose tolerance in our study $(\mathrm{R}=-0.891, \mathrm{P}=0.05)$ (data not shown) (Figure 3). Figure 3 shows that blood glucose values of each group gradually decreased and reach the lowest value at $60 \mathrm{~min}$ after the injection of insulin. Similarly, only blood glucose value of SD treated rats treating with $150 \mathrm{mg} \mathrm{kg}^{-1} \mathrm{~d}^{-1}$ of GSPE was significantly $(\mathrm{P}<0.05)$ lower compared with the control. Furthermore, the lowest value of blood glucose value at $60 \mathrm{~min}$ in SD treated rats was $2.1 \mathrm{mmol} / \mathrm{L}$, which was 19.2\% lower than compared with the control (Figure 3A). In addition, as for HFD treated rats, 50, 100 and $150 \mathrm{mg} \mathrm{kg}^{-1} \mathrm{~d}^{-1}$ of GSPE decreased blood glucose value by $5.7 \%, 17.1 \%$ and $40 \%$ after the injection of insulin compared with the control at $60 \mathrm{~min}$, respectively (Figure 3B). What is more, 100 and $150 \mathrm{mg} \mathrm{kg}^{-1} \mathrm{~d}^{-1}$ of GSPE remain exhibited excellent effect which was similar to the results of Figure $2 \mathrm{~B}$. A significantly $(\mathrm{P}<0.05)$

\begin{tabular}{|c|c|c|c|c|c|}
\hline \multirow{2}{*}{ Rats } & \multirow{2}{*}{ Treatment } & \multicolumn{4}{|c|}{ Serum lip level (mmol/L) } \\
\hline & & TC & TG & HDL-C & LDL-C \\
\hline \multirow{4}{*}{ SD } & Control & $1.7 \pm 0.02 \mathrm{a}$ & $0.8 \pm 0.06 a$ & $1.2 \pm 0.10 \mathrm{a}$ & $3.2 \pm 0.07 a$ \\
\hline & $50 \mathrm{mg} \mathrm{kg}^{-1} \mathrm{~d}^{-1}$ & $1.7 \pm 0.01 \mathrm{a}$ & $0.8 \pm 0.02 a$ & $1.2 \pm 0.05 a$ & $3.2 \pm 0.03 a$ \\
\hline & $100 \mathrm{mg} \mathrm{kg}^{-1} \mathrm{~d}^{-1}$ & $1.5 \pm 0.05 b$ & $0.7 \pm 0.02 b$ & $1.3 \pm 0.02 b$ & $2.8 \pm 0.02 b$ \\
\hline & $150 \mathrm{mg} \mathrm{kg}^{-1} \mathrm{~d}^{-1}$ & $1.5 \pm 0.04 \mathrm{c}$ & $0.6 \pm 0.05 c$ & $1.4 \pm 0.03 c$ & $2.4 \pm 0.07 b$ \\
\hline \multirow{4}{*}{ HFD } & Control & $1.9 \pm 0.06 \mathrm{a}$ & $1.4 \pm 0.08 a$ & $1.3 \pm 0.01 \mathrm{a}$ & $3.5 \pm 0.05 a$ \\
\hline & $50 \mathrm{mg} \mathrm{kg}^{-1} \mathrm{~d}^{-1}$ & $1.8 \pm 0.01 \mathrm{a}$ & $1.3 \pm 0.06 a$ & $1.3 \pm 0.03 \mathrm{a}$ & $3.4 \pm 0.02 a$ \\
\hline & $100 \mathrm{mg} \mathrm{kg}^{-1} \mathrm{~d}^{-1}$ & $1.7 \pm 0.03 b$ & $1.2 \pm 0.02 b$ & $1.4 \pm 0.05 b$ & $3.3 \pm 0.07 b$ \\
\hline & $150 \mathrm{mg} \mathrm{kg}^{-1} \mathrm{~d}^{-1}$ & $1.6 \pm 0.04 \mathrm{c}$ & $1.1 \pm 0.02 \mathrm{c}$ & $1.5 \pm 0.09 c$ & $3.3 \pm 0.09 b$ \\
\hline
\end{tabular}

All means in the same column followed by different letters (a-c) are significantly $(P<0.05)$ different by Duncan's multiple range test

Table 2: Effect of GSPE on serum lip level of standard diet and high fat diet treated rats.

lower blood glucose value in $100 \mathrm{mg} \mathrm{kg}^{-1} \mathrm{~d}^{-1}$ of GSPE treatment was found with respect to the control. In particular, $150 \mathrm{mg} \mathrm{kg}^{-1} \mathrm{~d}^{-1}$ of GSPE relatively showed best effect, which was significant $(\mathrm{P}<0.01)$ compared with the control group (Figure $3 \mathrm{~B}$ ). Thus, our results demonstrated that $150 \mathrm{mg} \mathrm{kg}^{-1} \mathrm{~d}^{-1}$ of GSPE was appropriate to improve insulin sensibility of HFD treated rats.

\section{Gene expression of lipid-associated genes in liver}

Lipid content in animal body is a state of relative balance between adipose synthesis and lipolysis $[1,23]$. However, adipose synthesis and lipolysis are regulated by lipid metabolism related genes $[19,24]$. In our present study, to investigate the effect of GSPE on expression of adipose synthesis related genes and lipolysis related genes in standard diet and high fat diet treated rats, the mRNA relative level of FAS, ACC1, Cpt1a and HSL was examined by the real-time PCR method (Figure 4). Figure $4 \mathrm{~A}$ showed that the gene expression level of FAS and ACC1 in liver of rats were effectively suppressed in varying degree by GSPE of different doses treatment compared with the control, particularly for HFD treated rats,
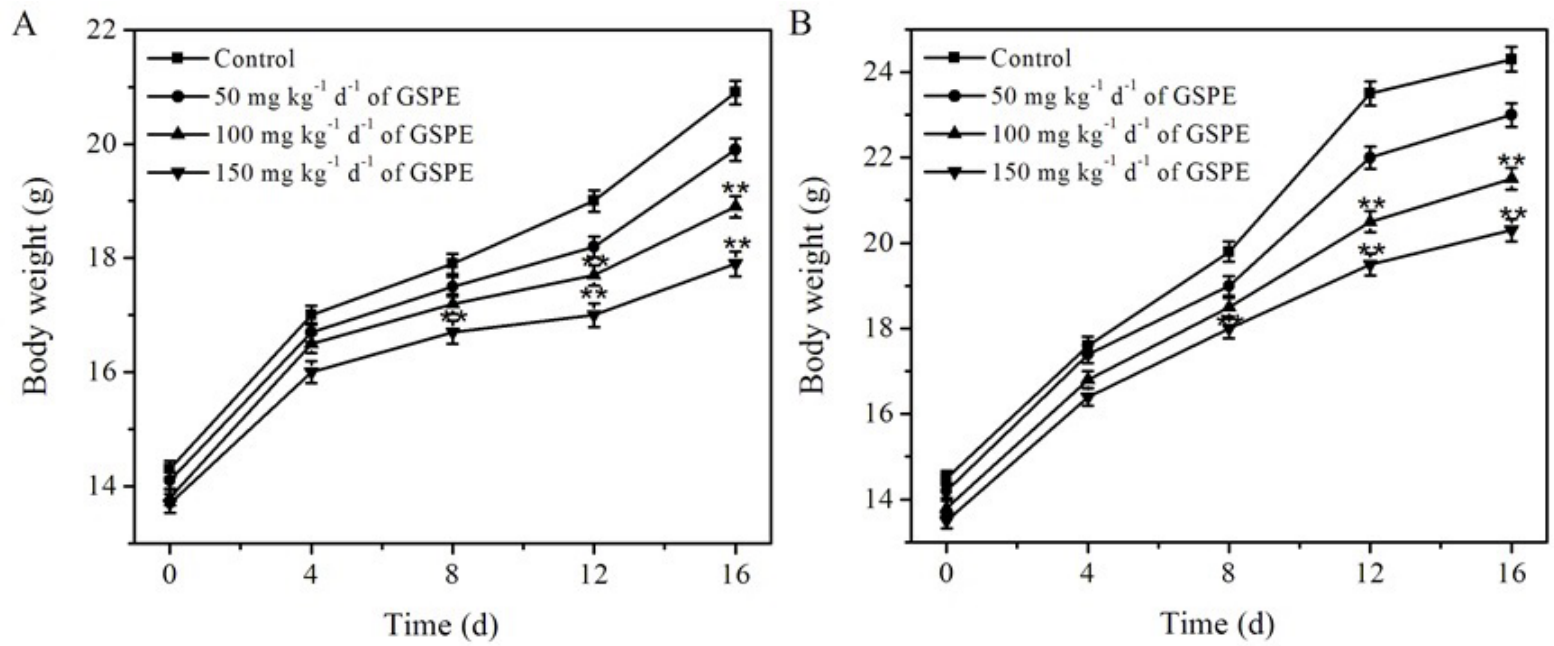

Figure 1: Effect of GSPE on body weight of standard diet treated rats (A) and high fat diet treated rats $(B)$. Each value is a mean of three replications \pm SE. "Mean significant at $P<0.01$ and ${ }^{*}$ Mean significant at $P<0.05$. 

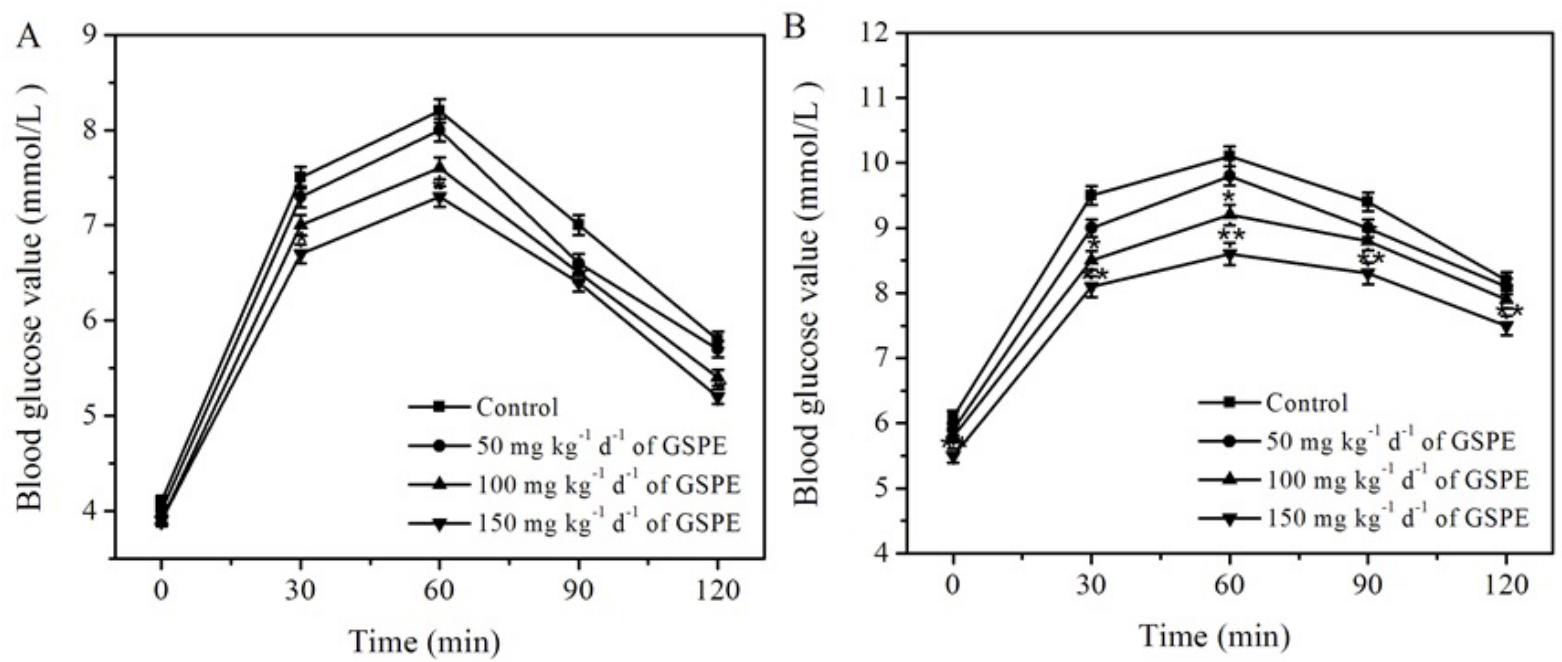

Figure 2: Effect of GSPE on glucose tolerance of standard diet treated rats $(A)$ and high fat diet treated rats $(B)$. Each value is a mean of three replications \pm SE. ${ }^{* *}$ Mean significant at $P<0.01$ and ${ }^{*}$ Mean significant at $P<0.05$.
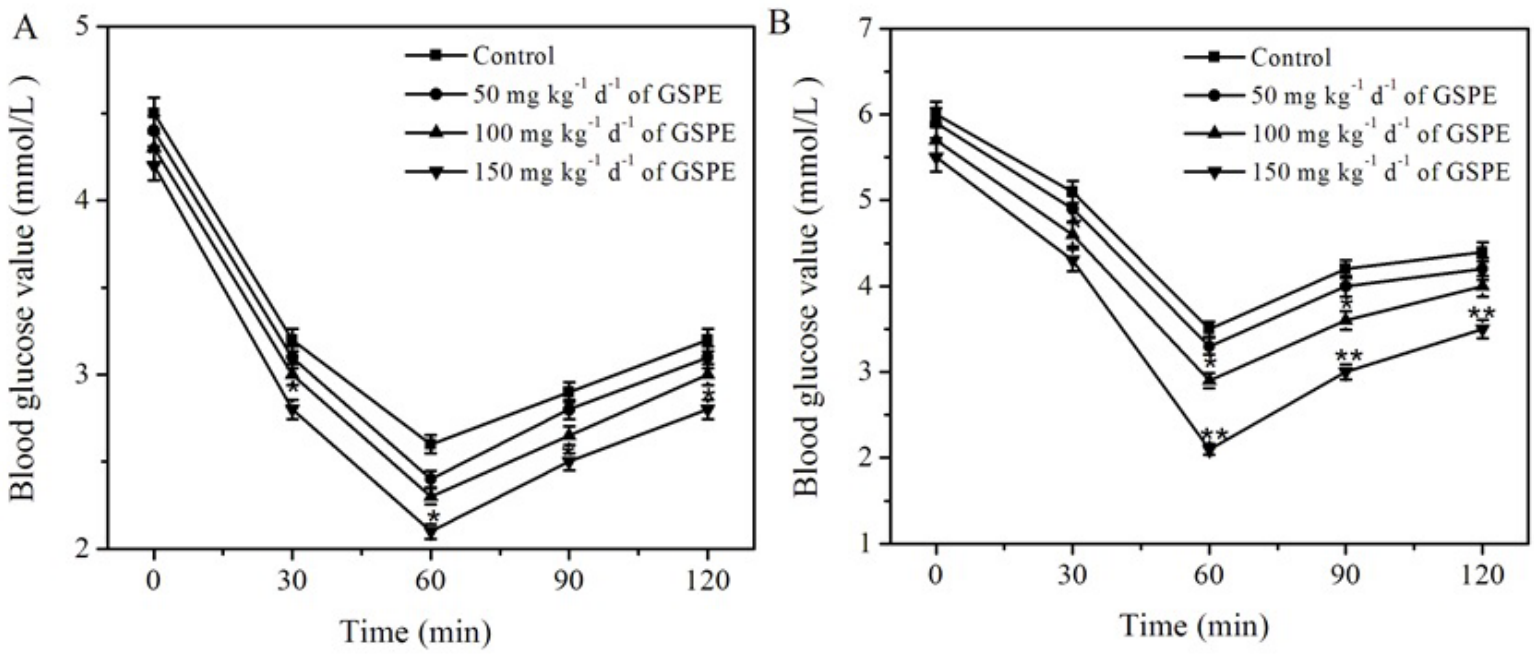

Figure 3: Effect of GSPE on insulin tolerance of standard diet treated rats $(A)$ and high fat diet treated rats (B). Each value is a mean of three replications \pm SE. ** Mean significant at $P<0.01$ and ${ }^{*}$ Mean significant at $P<0.05$.

the inhibitory effect was obvious. $150 \mathrm{mg} \mathrm{kg}^{-1} \mathrm{~d}^{-1}$ of GSPE significantly $(\mathrm{P}<0.05)$ suppressed gene expression level of FAS and ACC1 in liver of SD treated rats by $40 \%$ and $50 \%$ compared to untreated group, but no significant difference $(\mathrm{P}>0.05)$ was observed in samples which treated with low doses of GSPE (Figure 4A). Additionally, FAS and ACC1 expression level of HFD treated rats treating with $100(\mathrm{P}<0.05)$ and 150 $\mathrm{mg} \mathrm{kg}^{-1} \mathrm{~d}^{-1}$ of GSPE $(\mathrm{P}<0.01)$ were significantly suppressed compared with the control (Figure 4A). As shown in Figure 4B, gene expression levels of Cptla and HSL in liver of rats were effectively increased in varying degree by GSPE of different doses treatment compared with the control. Coincidentally, only $150 \mathrm{mg} \mathrm{kg}^{-1} \mathrm{~d}^{-1}$ of GSPE presented significantly difference $(\mathrm{P}<0.05)$ in $\mathrm{SD}$ treated rats when compared with control (Figure 4B). Maximal increase $(\mathrm{P}<0.01)$ of both Cpt1a and HSL expression level were observed in HFD treated rats with $150 \mathrm{mg} \mathrm{kg}^{-1} \mathrm{~d}^{-1}$ of GSPE, as compared to the untreated rats. However, $100 \mathrm{mg} \mathrm{kg}^{-1} \mathrm{~d}^{-1}$ of GSPE significantly $(\mathrm{P}<0.05)$ increased gene expression level of $\mathrm{Cptla}$ and HSL in liver of HFD treated rats by $60 \%$ and $42 \%$ compared to untreated group. Obviously, it can be seen that there was no statistically significant difference $(\mathrm{P}>0.05)$ between the effect of $50 \mathrm{mg} \mathrm{kg}^{-1} \mathrm{~d}^{-1}$ of GSPE and control (Figure 4B). As a whole, of the various doses of GSPE tested, application of $150 \mathrm{mg} \mathrm{kg}^{-1} \mathrm{~d}^{-1}$ was found to be most effective in suppressing adipose synthesis related genes expression and increasing lipolysis related genes expression in liver of rats.

\section{Discussion}

Senescence is an extremely complex and inevitable physiological phenomenon during human life. Presently, free radical theory proposed by Harman in 1956 is one of the most representative senescence theories [25]. It is reported that there are antioxidant enzyme systems that eliminates free radicals in human body, such as superoxide dismutase (SOD) and glutathione peroxidase (GSH-Px) [26]. However, the synthesis and activity of antioxidants decline with age, and a large 


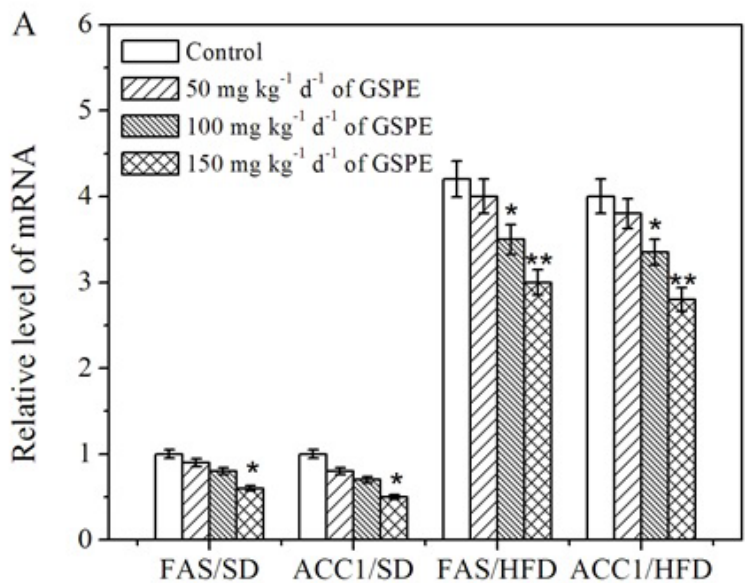

Gene

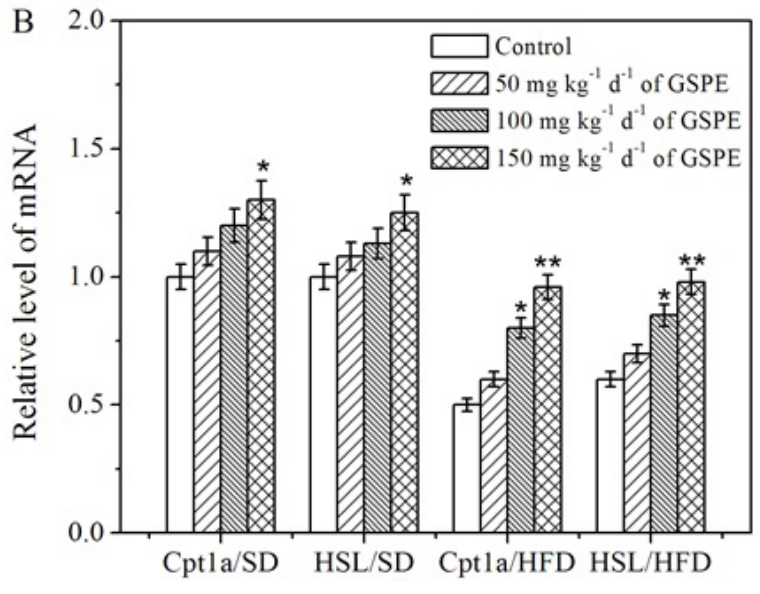

Gene

Figure 4: Effect of GSPE on expression of adipose synthesis related genes (A) and lipolysis related genes (B) in standard diet and high fat diet treated rats. Each value is a mean of three replications \pm SE. ${ }^{* *}$ Mean significant at $P<0.01$ and ${ }^{*}$ Mean significant at $P<0.05$.

number of malonaldehyde (MDA) produce which results in a massive accumulation of free radicals, thereby the senescence of human body accelerate. Recent studies have found that grape seed has high nutritional and medicinal value, and GSPE is one of the important components of grape seed bioactive substances. GSPE has the ability to eliminate free radicals and suppress lipid peroxidation because of the polyelectron hydroxyls in GSPE molecule [27]. Therefore, at present, GSPE is found one of the most effective oxygen radical eliminators and lipid peroxidation inhibitors. The present study indicated that $150 \mathrm{mg} \mathrm{kg}^{-1} \mathrm{~d}^{-1}$ of GSPE was a promising dose, which inhibited the lipid deposition by decreasing body weight, serum lip level and blood glucose value, improving the trend of high blood glucose and insulin resistance, suppressing FAS and ACC1 genes expression levels and increasing Cptla and HSL genes expression levels in liver of rats. Our experiment results also showed that there was decrease in body weight of various doses of GSPE-treated rats in comparison with control group, but no statistically significant difference $(\mathrm{P}>0.05)$ was found between the body weight of untreated and every doses of GSPE-treated rats during the first four days. We think the reason for this observation was that various doses of GSPE have little impact on body weight of rats during the first four days. Furthermore, GSPE showed the doseindependent manner. In conclusion, the results suggested that GSPE can affect gene expression levels of related with lipid metabolism and plays an beneficial role in preventing the production of obesity and treating obesity.

\section{Acknowledgements}

The study was supported by China Spark Program Project (2015GA650007).

\section{Conflict of Interest}

The authors have no conflicts of interests to report.

\section{References}

1. Ozcan U, Cao Q, Yilmaz E, Lee AH (2004) Endoplasmic reticulum stress links obesity, insulin action, and type 2 diabetes. Science 306: 457-461.

2. Petro AE, Cotter J, Cooper DA (2004) Fat, carbohydrate and calories in the development of diabetes and obesity in the C57BL/6J mouse. Metabolism 53: 454-457.

3. Cordain L, Melby CL, Hamamoto AE, Neill DS (2000) Influence of moderate chronic wine consumption on insulin sensitivity and other correlates of syndrome X in moderately obese women. Metabolism 49: 1473-1477.

4. Juhel C, Armand M, Pafumi Y, Rosier C, Vandermander J (2000) Green tea extract $(A R 25(R))$ inhibits lipolysis of triglycerides in gastric and duodenal medium in vitro. J Nutr Biochem 11: 45-51.

5. Hirosumi J, Tuncman G, Chang L, Gorgun CZ (2002) A central role for JNK in obesity and insulin resistance. Nature 420: 333-336.

6. Levin BE, Triscari J, Sullivan AC (1986) Metabolic features of diet-induced obesity without hyperplasia in young rats. Am J Physiol 251: 433-440.

7. Kao YH, Hiipakka RA, Liao S (2000) Modulation of obesity by a green tea catechin. Am J Clin Nutr 72: 1232-1234.

8. DellAgli M, Bosisio E (2002) Biflavones of ginkgo biloba stimulate lipolysis in 3T3-L1 adipocytes. Planta Med 68: 76-79.

9. Li WG, Zhang XY, Wu YJ, Tian X (2000) Anti-inflammatory effect and mechanism of proanthocyanidins from grape seeds. Acta Pharmacol Sin 22 1117-1120.

10. Del BJM, Fern'andez LJ (2005) Grape seed procyanidins improve atherosclerotic risk index and induce liver CYP7A1 and SHP expression in healthy rats. FASEB J 19: 479-481.

11. Pinent M, Blay M, Blade MC, Salvado MJ (2004) Grape seed-derived procyanidins have an antihyperglycemic effect in streptozotocin-induced diabetic rats and insulinomimetic activity in insulin-sensitive cell lines. Endocrinology 145: 4985-4990.

12. Terra X, Montagut G, Bustos M (2009) Grape-seed procyanidins prevent lowgrade inflammation by modulating cytokine expression in rats fed a high-fat diet. Journal of Nutritional Biochemistry 20: 210-218.

13. Lluis L, Munoz M, Nogués M (2010) Genotoxicity and acute toxicity of the procyanidin-rich extract from grape seeds. Toxicology Letters 196: 345-351.

14. Yamakoshi J, Saito M, Kataoka S (2002) Safety evaluation of proanthocyanidinrich extract from grape seeds. Food and Chemical Toxicology 40: 599-607.

15. Mittal A, Elmets CA, Katiyar SK (2003) Dietary feeding of proanthocyanidins from grape seeds prevents photocarcinogenesis in SKH-1 hairless mice: relationship to decreased fat and lipid peroxidation. Carcinogenesis 24: 13791388.

16. Moreno DA, llic N, Poulev A (2003) Inhibitory effects of grape seed extract on lipases. Nutrition 19: 876-879.

17. Lopiz N, Puiggros F, Cespedes E (2004) Antigenotoxic effect of grape seed procyanidin extract in Fao cells submitted to oxidative stress. J Agric Food Chem 52: 1083-1087.

18. Tebib K, Besan P, Rouanet JM (1996) Effects of dietary grape seed tannins on 
Citation: Fangxu X, Yefei L, Xinzhe Z, Shengzhong D (2017) Effect of Grape Seed Procyanidins Extract on Lipolysis in Rats. J Bioprocess Biotech 7: 312. doi:10.4172/2155-9821.1000312

rat cecal fermentation and colonic bacterial enzymes. Nutr Res 16: 105-110.

19. Charradi K, Sebai H, Elkahoui S (2011) Grape seed extract alleviates highfat diet-induced obesity and heart dysfunction by preventing cardiac siderosis. Cardiovasc Toxicol 11: 28-37.

20. Bladé C, Arola L, Salvadó MJ (2010) Hypolipidemic effects of proanthocyanidins and their underlying biochemical and molecular mechanisms. Mol Nutr Food Res 54: 37-59.

21. Bobulescu IA (2010) Renal lipid metabolism and lipotoxicity. Curr Opin Nephrol Hypertens 19: 393-402.

22. Figueira TR, Ribeiro RA, Ignacio SLM, Vercesi AE (2012) Enhanced insulin secretion and glucose tolerance in rats exhibiting low plasma free fatty acid levels and hyper tri glyceridaemia due to congenital albumin deficiency. Experimental Physiology 97: 525-533.
23. Wang H, Wei G (2004) Composition of body elements and judgement of fatness. J Shenyang Norm Univ (Nat Sci). 2: 142-144.

24. Charradi K, Elkahoui S, Karkouch I (2013) Grape seed and skin extract alleviates high-fat diet-induced renal lipotoxicity and prevents copper depletion in rat. Applied Physiology Nutrition and Metabolism 38: 259-267.

25. Harman D (1956) Aging: A theory based on free radical and radiation chemistry. Journal of Gerontology 11: 298-300.

26. Das N, Levine RL, Orr WC (2001) Selectivity of protein oxidative damage during aging in Drosophila melanogaster. Biochemical Journal 360: 209-216.

27. Finkel T, Holbrook NJ (2000) Oxidants, oxidative stress and the biology of aging. Nature 408: 239-247. 